\title{
Evaluation of Information Quality on the Website of Mimika Regency Government
}

\author{
Alim Magal \\ Information System, Kristen Satya Wacana \\ University, Salatiga, 50715, Indonesia \\ 682014606@student.uksw.edu
}

\author{
Melkior N. N. Sitokdana* \\ Information System, Kristen Satya Wacana \\ University, Salatiga, 50715, Indonesia \\ melkior.sitokdana@uksw.edu \\ *Corresponding Author
}

Received: 2021-08-11; Revised: 2021-08-24; Accepted: 2021-08-29; Published: 2021-09-01

\begin{abstract}
- the current development of economic, political and technological globalization demands the implementation of an orientation of Good and Clean Government. To achieve this objective, the Indonesian government from central to regional level is required to implement an application of information and communication technology to improve effectiveness, efficiency, transparency and also accountability of public services. From the results of research and also from the results of audit of e-Government at local government level, apparently government's websites on average are at the first level (preparation level), only a few of government's websites have reached the second level (maturation level), while the third level (solidification level) and the fourth level (utilization level) have not been reached by government's websites. This condition is influenced by the complexity of problems in Indonesia, such as the inequality of facilities and infrastructure, the low quality of human resources, high poverty rates, etc. Therefore, this research is conducted to evaluate the quality of the Mimika regency's website. For a long time, the Mimika government has owned the website: http://www.mimikakab.go.id/. Therefore, it will be very interesting to evaluate and recommend the result of evaluation to stakeholders so that steps can be taken for a tactical and strategic development.
\end{abstract}

Keyword-Evaluation, Quality, Information System, Government, Mimika Regency

\section{INTRODUCTION}

The current development of economic, political and technological globalization demands the implementation of an orientation of Good and Clean Government. To achieve this objective, the Indonesian government from central to regional level is required to implement an application of information and communication technology to improve effectiveness, efficiency, transparency and also accountability of public services and improve government business processes, either in the context of inter-government relationship (G2G), government to business relationship (G2B), government to civil servant relationship (G2E), and government to society relationship $(\mathrm{G} 2 \mathrm{C})$.

The implementation of information technology applications and also communication of government organizations is more popularly known as "eGovernment". One of the e-Government services that the government must have is Website service. Website service is also one of the important aspects in eGovernment. Like building a house that must be started with building of foundation of the house, the development of e-Government applications must be started with a making of government's websites. In general, government's websites should contain government profile, organizational structure, vision and mission, work programs, development strategies, news/announcements, links to organizational unit, links to e-Government services, budget accountability reports, planning documents, and so on. Government's websites must have good quality contents that are available in realtime. Unfortunately, not all government organizations are able to produce this idea because they encounter several problems.

Based on the results of research and also based on the audit of e-Government management at local level, on average, most government's websites are at the first level (preparation), only a small percentage of them have reached the second level (maturation), and none of them have reached the third level (consolidation) and the fourth level (utilization) (R. Febriani, 2016). This is influenced by the complexity of problems occurring in Indonesia, such as the inequality of facilities and infrastructure, the low quality of human resources, the high poverty rates, the unstable economic conditions, the worsening political conditions at national level, and a poor performance of government officials.

In his research in Sitokdana, Melkior found that the websites that are owned by the regional Governments in Java are better in their quality than the websites in other regions, including the website that is owned by the Jayapura City government, which in his case study, it is stated that the website of the Jayapura City government does not meet the standards required by the existing regulations, while as the oldest city in Papua, the Jayapura City Government should be a benchmark of eGovernment development in Papua. Although in terms of quantity, the development of local government websites is increasing rapidly, the development still lacks of quality because not all of local government websites provide facilities for standardized public services and those websites were made only to meet the requirement 
of public information disclosure without changes in ebased government work management (M. N. N. Sitokdana, 2015)

For this reason, this research was conducted to evaluate the quality of the website of Mimika Regency government, which the government of Mimika Regency has long had a website domain: http://www.mimikakab.go.id/.

The website contains menus: home, subdomains, regional profile, government, information, documents, and news. Based on the research, various shortcomings and weaknesses were found that needed to be evaluated. Recommendations need to be given to the policy makers. In an interview with an officer who was responsible for the management of the website, he said that so far evaluations had not been made regarding of the quality of the website. Therefore, recommendation to stakeholders is necessary to make adjustment tactically and strategically.

This research uses 2 instruments to evaluate the quality on the website of Mimika Regency Government, namely: the standard of content stipulated by PKOMINFO for websites of local governments and twenty dimensions of quality in information according to Knight \& Burn (Johandi, Kambey, and Sitokdana 2020). The evaluation of the quality of information was carried out from January 1 to February 6, 2019.

The evaluation aims to identify weaknesses, explore solutions and recommendations for formulation appropriately and continuously of e-Government development strategies in Mimika Regency.

\section{OVERVIEW OF HERITAGE AND THEORY}

\section{A. Previous Research}

This research with the topic "Evaluation of Local Government' Website in Indonesia" is not a new topic because previous studies had been made using this topic that are also used as references in this study, among others:

Sitokdana, Melkior's research entitled: "Evaluation of e-Government Implementation on the Municipal Government's Websites of Surabaya, Medan, Banjarmasin, Makassar and Jayapura". Several indicators were also used to evaluate the quality of those websites, namely the aspects of transparency, service, efficiency, economy, aspirations, appearance, updates and stages in achieving e-Government goals. The results of their research showed that Surabaya City was much better than other cities. This result is the same as the result of PeGi's evaluation in 2012-2014 that in ranking e-Government websites so far has only been dominated by the local government in Java. For this reason, it is necessary to recommend several things to improve the quality of eGovernment websites, namely the improvement of the website contents and also in e-Leadership specifications, Infrastructure in Information Networks, Information Management, Business Environment, Society and Human Resources that should be well formulated in the Strategic Plan so that the website development and implementation can be carried out thoroughly (M. N. N. Sitokdana, 2015).

In the results of research done by Tonggiroh, Mursalim entitled: "Digital Government Services in Papua" show the same indicators for evaluating Government's websites in Papua Province, Jayapura City, Jayapura Regency, Merauke Regency, and Jayawijaya Regency. The results of the study also show that the implementation of e-Government in Papua was still far below the ideal standard. Although in terms of complexity and time, e-Government services of regional government of Papua Province had reached the Interaction Stage, the level of performance and the effectiveness of e-Government had not provided significant benefits to guests (M. Tonggiroh, 2018).

A study conducted by Damanik, Marudur $\mathrm{P}$ with a title: "E-Government and Its Application in Local Government Environments (Case Study of the Information Quality of Website of Bengkalis Regency, Riau Province)" aims to measure the quality of information on four websites owned by the Bengkalis Regency government based on dimensions of Accuracy, Completeness, Recency, Relevance, Availability through a method of interview with those who managed those websites. The results of the study show that the information available on the Bengkalis Regency Government's websites has met the quality of good information, although there were some shortcomings such as links of the websites were blank pages, the information about calendar was not yet available, and there was also no guarantee of network quality to ensure the availability of information (Damanik and Purwaningsih, 2017).

\section{B. Theoretical Foundation}

The World Bank (2012) refers e-Government to the use by government agencies of the information technologies (such as the WAN, the internet and mobile computing) that have the abilities to transform relation with the citizens, business, and other arms of government." This definition confirms that e-Government refers to the use of information technology such as WAN network, the Internet and also government mobile computing for the transformation of relations with society (G2C), with business (G2B) and also between governments (G2G). According to Rahardjo, Budi, eGovernment is defined as an interactive system of communication and also a coordination between the government and its citizens, its business entities, and other government units by using web-based electronic technologies and other technologies (Noviana, Sulandari, and Lituhayu, 2015).

Meanwhile, according to Pascual, PJ, e-Government can be defined as the use of information that can improve relations between the government and other parties because it involves computerization in paper-based procedures that encourages new ways of in leading, discussing and determining of strategies, doing business, listening to citizens and communities as well as in 
organizing and conveying information (O. Somantri 2017).

The benefits of implementing e-Government are: (1) Improving the quality of government services to its stakeholders (community, business and industry) especially in terms of effective and efficient performance of various people lives; (2) Increasing transparency, control, and accountability in the administration of government in the context of implementing the concept of good corporate governance; (3) Significantly reduce the totality of administration, relations \& interactions issued by the government and its stakeholders for the purposes of daily activities. (4) Provide opportunities for the government to obtain new sources of income by interacting with interested parties; (5) Creating a new community environment that correctly answers the encountered problems, various global changes, and existing trends. (6) Empowering other parties as government partners in the process of making public policies equally and democratically (M. Riadi 2020).

The benefits of implementing e-Gov can also be measured by the quality of information, although the level of information quality is difficult to measure. The quality of information cannot be judged independently by a single person for another person. Rieh argues that information users can only judge the quality of information for their own sake and as a result it creates a subjective value so that information can be valuable to certain parties but not to other parties (Jirzanah, 2016). Dimensions of Information Quality according to Knight \& Burn (Johandi, Kambey, and Sitokdana, 2020) by citing some of Wang \& Strong's dimensions are as Table 1 .
Table 1 - Information Quality Dimensions

\begin{tabular}{|c|c|}
\hline $\begin{array}{c}\text { Dimension of } \\
\text { information quality }\end{array}$ & Definition \\
\hline Accuracy & Errors-Free Information \\
\hline Consistency & $\begin{array}{l}\text { Does Not Contain Contradictive } \\
\text { Information }\end{array}$ \\
\hline Security & $\begin{array}{l}\text { Certain information is Limited } \\
\text { Properly }\end{array}$ \\
\hline Timeliness & Information is Available In Time \\
\hline Newness & $\begin{array}{l}\text { Information is Updated At All } \\
\text { Times/Updated Based on Needs }\end{array}$ \\
\hline Completeness & No Missing Information \\
\hline Conciseness & $\begin{array}{l}\text { Information is Concise and } \\
\text { Precise }\end{array}$ \\
\hline Reliability & Information is Reliable \\
\hline Reachability & Information is Easily Retrievable \\
\hline Availability & $\begin{array}{l}\text { Information Can be Accessed At } \\
\text { Anytime }\end{array}$ \\
\hline Objectivity & $\begin{array}{l}\text { Information Is Unbiased and } \\
\text { Impartial }\end{array}$ \\
\hline Relevance & $\begin{array}{l}\text { Information Is Useful And Can } \\
\text { Be Used At Anytime }\end{array}$ \\
\hline Usage Easiness & $\begin{array}{l}\text { Information Is Clear and Easy } \\
\text { To Use }\end{array}$ \\
\hline Amount of Data & $\begin{array}{l}\text { Sufficient Available Information } \\
\text { To Be Accessed }\end{array}$ \\
\hline Trust & $\begin{array}{l}\text { Information Is Trustworthy And } \\
\text { Credible }\end{array}$ \\
\hline Navigation & $\begin{array}{llr}\text { Information Is } & \text { Easily } & \text { Found } \\
\text { And Related } & \text { To } & \text { Other } \\
\text { Information } & & \\
\end{array}$ \\
\hline Reputation & $\begin{array}{lcr}\text { Information Can } & \text { Be } & \text { A } \\
\text { Trustworthy Reference } & & \\
\end{array}$ \\
\hline Usefulness & $\begin{array}{ll}\text { Information Helps } & \text { The } \\
\text { Smoothness of Tasks } & \\
\end{array}$ \\
\hline Efficiency & $\begin{array}{l}\text { Information Helps } \\
\text { Smoothness of Tasks }\end{array}$ \\
\hline
\end{tabular}

Based on the nature of information transactions and public services that have been provided by the government through information networks, and the development of e-Gov can be carried out in 4 (four) levels as follows:

\section{RESEARCH METHODS}

The qualitative descriptive method was used in this research i.e. the study of the Evaluation of the Quality of e-Government Information on the website of Mimika Regency Government. According to Nawawi and Martini, a qualitative descriptive research describes the object of research based on facts (Angreni and Sari, 2017). According to Mukhtar, a qualitative descriptive research seeks to describe all existing symptoms or conditions, namely the real state of symptoms when the research is conducted (A. C. Tunggal, 2015). In the context of this research, the method describes the contents on the website with two instruments, namely (1) the local government website standards set by DEPKOMINFO and (2) 20 dimensions of information quality according to Knight and Burn (Johandi, Kambey, and Sitokdana, 2020). 
This research uses secondary data sources, namely studies of literatures, articles, journals and observations as well as an in-depth search on the content of the website of Mimika Government, namely: http://www.mimikakab.go.id/The Evaluation of Information Quality of the website were conducted from 10 October to 5 December 2020.

\section{RESULT AND DISCUSSION}

\section{A. Analysis of the Website Standards of Mimika Regency Government}

This section discusses the extent of e-Government made by the Mimika Regency government on its website and the extent of meeting the minimum standards for local government websites set by the Ministry of Communication and Information. The first question will be answered by evaluating the current condition of the government's website from January 1 to February 6, 2019. The following is the main display of the Mimika Regency website of http://www.mimikakab.go.id/ shown in Picture 1.

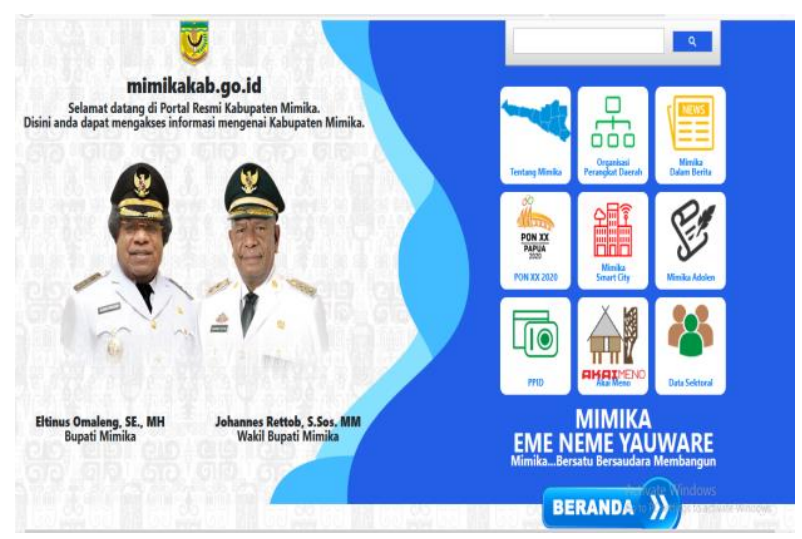

Picture 1. Dimensions of Information Quality

Picture 1 shows, that there are 9 e-Planning applications, namely: "About Mimika", "Regional Apparatus Organizations", "Mimika In the News", "PON XX 2020", "Mimika Smart City", "Mimika Adolen", "PPID", and "Akai Meno and Sectoral Data". Each ePlanning application can be explained as follows: (1) Tentang Mimika (About Mimika) which is an e-Planning application that contains the geographical location as well as the area and boundaries of the Mimika Regency, (2) Organisasi Perangkat Daerah (Regional Apparatus Organization) (OPD) which is an e-Planning application that contains 40 Sub Menus, namely 40 SKPD/Section Heads containing photos of section heads and secretaries along with their Vision and Mission, (3) Mimika Dalam Berita (Mimika in the News) which is an e-Planning application that updates the latest news, (4) PON XX 2020 (National Sport Event) which is an e-Planning application that updates the latest news about the development of the National Sports Event which will be held in 2020, (5) Mimika Smart City which is an ePlanning application that updates on the development and use of e-Government for the development of Natural Resources and Human Resources, (6) Adolen Wisata (Adolen Toursim) which is an e-Planning application that plays a role in the use of e-Government to display various kinds of tourism in Mimika Regency, (7) PPID which is an e-Planning application which its role is to register document applications, (8) Akai Meno that contains the messages of Warning and Potential Security Risks Ahead, and (9) Statistik Sektoral (Sectoral Statistics) which is an e-Planning application which its role is to display the formula for economic development. However, apparently the data has not been uploaded because there is only a brief description of how to calculate economic growth. Links for download and folders for online documents can be accessed by the public. In addition, the link of Mimika Regency official website displays the homepage on the main page.

"Beranda" (Home) is the front view of the website. This page also displays the latest news, important announcements, and links of e-Government applications i.e., Electronic Procurement Service application, and Mimika e-Planning application. In addition, it displays 10 website page menus, namely "Tentang Kami (About Us)", "Berita (News)", "Statistik Sektoral (Sectoral Statistics)", "Smart City", “Andolen", "PPID", "Pengumuman (Announcements)", "Agenda", "Galeri (Gallery)", and "Kontak (Contact)". Each page can be explained as follows: (1) Tentang Kami (About Us) is a web page that contains sub menus, namely "Selamat Datang (Welcome)" Sub Menu which displays the Speech of the Regional Head, "Tentang Mimika (About Mimika)" Sub Menu which displays the same thing as the display of e-Planning application about Mimika, "Visi dan Misi (Visions and Missions)" Sub Menu that displays the visions and missions along with photos of the Regency Head \& Deputy Regency Head, and "Organisasi Perangkat Daerah (Regional Apparatus Organization)" Sub Menu that displays the same as the display of the contents of the Regional Apparatus Organization (OPD) e-Planning Applications; (2) "Berita (News)" is a website page that contains several sub menus, namely: "Menu Lainnya (Other Sub Menu)" which updates the latest news, "Sosial (Social)" Sub Menu which updates social news, "Politik (Politics)" Sub Menu which updates political news, "Budaya (Culture)" Sub Menu which updates district cultural news of Mimika, "Ekonomi (Economy)" Sub-Menu that updates news related to the economy, "Lingkungan (Environment)" Sub-Menu that updates in relation to the Mimika Regency environment, "Olah Raga (Sports)" Sub-Menu that updates sports news, "Pendidikan (Education)" Sub-Menu that updates the education news, and "Teknologi (Technology)" SubMenu that updates the news and technology, although no news has been updated yet; (3) Statistik Sektoral (Sectoral Statistics) is a website page that displays the same content as the Sectoral Statistics e-Planning Application; (4) "Smart City" is a web page that displays the same as the Smart City e-Planning Application; (5) "Andolen" is a website page that displays several Sub Menus, namely "Obyek Turisme (Tourism Object) Sub 
Menu which updates the same content as the content of Adolen Wisata e-planning application, "Kuliner (Culinary) Sub Menu that updates photos and descriptions of regional specialties. The "Sovenir (Souvenirs)" Sub Menu that updates photos and displays regional clothes and regional motif paintings, "Prestasi (Achievements)" Sub Menu that updates the contents of souvenirs; (6) PPID is a website page that displays several sub menus, namely: "Permohonan Informasi/Dokumen (Information/Document Request)" Sub Menu which displays the same content as the content of PPID e-Planning application, "Daftar Informasi Berkala (Periodic Information List)" Sub Menu that displays a list of periodic information based on their categories that are accompanied with links of downloadable files, "Daftar Informasi Setiap Saat (Updated Information List)" Sub Menu that displays forms of death, forms of birth report and the yellow card requirements. Although the links for downloaded files and folders do not contain necessary documents that can be accessed by the public, "Daftar Informasi Serta Merta (List of Additional Information)" Sub Menu is a sub menu that displays inspection activities for the construction of the facilities and infrastructures of livestock production market that are accompanied with links of downloaded files and folders. Although no necessary documents can be accessed by the public; (7) "Pengumuman (Announcement)" is a website page that displays the format for the Mimika Regency Government Civil Servant Candidates and the Announcement of the Final Results of the 2018 National Civil Service Candidate Selection. However, it seems that the data had not yet been uploaded and there was only a single display containing links of documents and folders with no documents that can be accessed by the public; (8) "Agenda" is a website page that displays the most important agendas based on date; (9) "Galeri (Gallery)" is a website page that displays 2 sub menus, namely: Photos and Videos containing photos and videos along with their descriptions; (10) "Kontak (Contact)" is a website page that displays a contact form that can accessed by related parties by filling out the name, email, mobile phone number and message in the form. Table 2 shows, analysis of the quality of information on the website of Mimika regency government.

Table 2. Information Quality Analysis of the Website of Mimika Regency Government

\begin{tabular}{|c|c|c|}
\hline $\begin{array}{c}\text { Dimension of } \\
\text { information quality }\end{array}$ & Evaluation & Recommendation \\
\hline Accuracy & $\begin{array}{l}\text { There are many errors in organizing contents and in managing } \\
\text { data and information, such as errors on the menu "e-planning } \\
\text { application", errors on menu "news", and problem of double } \\
\text { "news and documents" on homepage. }\end{array}$ & 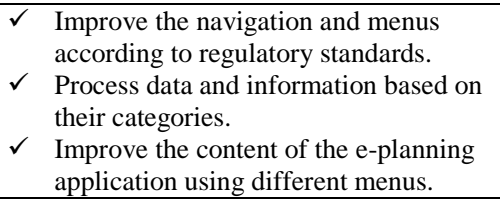 \\
\hline Consistency & $\begin{array}{l}\text { Inconsistent management of the navigation, menus and content } \\
\text { which most of them cannot be accessed properly. Also, } \\
\text { inconsistent management in the provision of data and information } \\
\text { which this problem exists in the menu of "Agenda } 1^{\text {st }} \text { September } \\
2019-10^{\text {th }} \text { October 2019". }\end{array}$ & $\begin{array}{l}\checkmark \text { Rearrange the navigation and links that } \\
\text { don't work properly. } \\
\checkmark \quad \text { Update data and information in real } \\
\text { time. }\end{array}$ \\
\hline Security & $\begin{array}{l}\text { The current website condition is not well managed so that other } \\
\text { parties can misuse it. }\end{array}$ & $\checkmark$ Perform control in real time. \\
\hline Timeliness & $\begin{array}{l}\text { The data and information so far are not timely provided and useful } \\
\text { for the public. For example, the document only contains the } \\
\text { documents of } 2018 \text { civil servant candidates and the message of " } 404 \\
\text { (missing content)". }\end{array}$ & $\begin{aligned} & \checkmark \text { Perform control in real time. } \\
& \checkmark \text { News and announcements must be } \\
& \text { updated. } \\
& \checkmark \text { Data concerning budget, } \\
& \text { accountability report, regulations, } \\
& \text { policies and public services must be } \\
& \text { updated. }\end{aligned}$ \\
\hline Newness & $\begin{array}{l}\text { Data and information are not available or they are not updated } \\
\text { regularly or they are not available according to the people's } \\
\text { needs. For example, in the menus of "Mimika in the News", } \\
\text { "Sectorial Statistics", and "Akai Meno", there are no data and } \\
\text { information available. }\end{array}$ & $\begin{array}{ll}\checkmark & \text { Improve the existing content. } \\
\checkmark & \text { Update data and information in real } \\
\text { time consistently and periodically. }\end{array}$ \\
\hline Completeness & $\begin{array}{l}\text { The available contents are not complete and have not met the } \\
\text { standards set by the Ministry of Communication and Information. }\end{array}$ & $\begin{array}{l}\text { Complete the navigation and contents in } \\
\text { accordance with the applicable } \\
\text { regulations. }\end{array}$ \\
\hline Conciseness & $\begin{array}{l}\text { The provided information and data should be concise and clear. } \\
\text { Unfortunately, several contents in the website are overlapping } \\
\text { which it can be seen from the content of e-planning application on } \\
\text { the homepage and the content in the menus of "Mimika" and } \\
\text { "souvenirs and achievements". }\end{array}$ & $\begin{array}{l}\text { The data and information provided are } \\
\text { concise, concise and clear. }\end{array}$ \\
\hline Reliability & Data and information are not yet reliable by the public. & $\begin{array}{l}\text { Make the website as the main means of } \\
\text { providing data and information for the } \\
\text { public. }\end{array}$ \\
\hline Reachability & $\begin{array}{l}\text { The website has not been reached by the public because data and } \\
\text { information are not available and can only be accessed by certain } \\
\text { people. }\end{array}$ & $\begin{array}{l}\checkmark \text { Use the website for public service } \\
\text { information } \\
\checkmark \text { Ensure that the public can access the } \\
\text { information about the government } \\
\text { services through the website }\end{array}$ \\
\hline
\end{tabular}




\begin{tabular}{|c|c|c|}
\hline & & $\begin{array}{l}\checkmark \text { Create and provide special links for } \\
\text { documents that can be accessed by the } \\
\text { public which are linked to local } \\
\text { websites. }\end{array}$ \\
\hline Availability & $\begin{array}{l}\text { Data and information cannot be accessed at any time. For example, } \\
\text { data on the menus of "Akai Meno", "Sectoral Statistics", and } \\
\text { "Technology". Therefore, this website is not yet ready for new data } \\
\text { and information. }\end{array}$ & $\begin{array}{l}\text { Ensure data and information are available } \\
\text { periodically. }\end{array}$ \\
\hline Objectivity & $\begin{array}{l}\text { The website still has not yet provided data and information } \\
\text { objectively and the domain name mimikakab.go.id still cannot be } \\
\text { accessed by the public in } 2021 \text {. }\end{array}$ & $\begin{array}{l}\text { Provide data and information whose } \\
\text { validity has been verified. }\end{array}$ \\
\hline Relevance & $\begin{array}{l}\text { The available information is not relevant to the public's needs and } \\
\text { the government's needs. }\end{array}$ & $\begin{array}{l}\text { Provide relevant information and data to } \\
\text { the public's needs and interests. }\end{array}$ \\
\hline Easy to Use & $\begin{array}{l}\text { The existing data and information are incomplete and cannot be } \\
\text { accessed by the public so that their utilization is not optimal. }\end{array}$ & $\begin{array}{l}\text { Ensure that the public can easily access } \\
\text { data and information. }\end{array}$ \\
\hline Amount of Data & The amount of data and information available is very limited. & $\begin{array}{ll}\checkmark & \text { Complete missing data. } \\
\checkmark & \text { Reduce double data. }\end{array}$ \\
\hline Trustworthy & $\begin{array}{l}\text { The available data and information is not fully trusted and used as } \\
\text { a reference due to inconsistency in their provisions. }\end{array}$ & $\begin{array}{l}\text { Always convince the public by providing } \\
\text { accurate, precise and accurate information } \\
\text { and data. }\end{array}$ \\
\hline Navigation & $\begin{array}{l}\text { Navigation and links cannot be connected to other information } \\
\text { such as the "akai meno" e-planning application and there are } \\
\text { several document attachments that cannot be accessed by the } \\
\text { public. }\end{array}$ & $\begin{array}{l}\text { Manage the navigation to be neat and } \\
\text { make sure that everything works well in } \\
\text { the navigation. }\end{array}$ \\
\hline Reputation & $\begin{array}{l}\text { The available data and information cannot be used as a reliable } \\
\text { reference. }\end{array}$ & $\begin{array}{l}\text { Provide complete data and information on } \\
\text { a regular basis so that it can be used as a } \\
\text { reference of development. }\end{array}$ \\
\hline Usefulness & $\begin{array}{l}\text { The available information does not help the public and businesses } \\
\text { in accessing public services and accessing regional development } \\
\text { information } \\
\text { The existing website and its contents is insufficient to facilitate the } \\
\text { government's tasks and make it easier for the public to access } \\
\text { public services. }\end{array}$ & $\begin{array}{l}\text { Prioritize useful data and information for } \\
\text { the public's interest. }\end{array}$ \\
\hline Efficiency & $\begin{array}{l}\text { The existing website and its contents is insufficient to facilitate the } \\
\text { government's tasks and make it easier for the public to access } \\
\text { public services }\end{array}$ & $\begin{array}{l}\text { Provide public service data and } \\
\text { information by ensuring that the public can } \\
\text { access it quickly, easily and cheaply. }\end{array}$ \\
\hline Added Values & $\begin{array}{l}\text { Currently, the available data and information on the website do not } \\
\text { provide added values to the public or to the internal government. }\end{array}$ & $\begin{array}{l}\text { Make the website as the main medium for } \\
\text { the realization of efficiency, effectiveness, } \\
\text { transparency and accountability of services } \\
\text { to the public. }\end{array}$ \\
\hline
\end{tabular}

\section{CONCLUSION}

Based on the results of the analysis and evaluation using the 10 dimensions of information quality, it can be concluded that, in general, the quality of information on the website of Mimika Regency Government is quite good. Some of the shortcomings found are generally caused by pages that use contrast colors which is less comfortable for the eyes and too many animations than the information that need to be displayed.

Based on these results, the researcher makes several suggestions i.e. first, the Mimika Regency Government should prioritize information over the style and sophistication of the website, second, the Mimika Regency Government should present real-time information on a regular basis, third, the Mimika Regency Government should ensure that data is complete by citing their sources, fourth, the Mimika Regency Government should give notice before the maintenance of the website is made, fifth, the Mimika Regency Government should give added values to the public's interest in making the website http://www.mimikakab.go.id/ as the main medium for a community-friendly information service in Mimika Regency.

\section{REFERENCES}

Damanik, M. P., \& Purwaningsih, E. H. (2018). Kesiapan E-Government Pemerintah Daerah Menuju Pengembangan Smart Province (Studi pada Pemerintah Kabupaten Mandailing Natal, Provinsi Sumatera Utara). Jurnal Studi Komunikasi dan Media, 22(2), 185-196.

Febriani, R. (2017). Gambaran e-Government di Indonesia yang Bersistem Desentralisasi Ditinjau dari Performa Situs Web Pemerintah Daerah. Nirmana, 16(1), 6472.

Jirzanah, J. (2016). Aktualisasi Pemahaman Nilai Menurut Max Scheler Bagi Masa Depan Bangsa Indonesia. Jurnal Filsafat, 18(1), 93-114.

Kambey, D. J. F., \& Sitokdana, M. (2020, February). Evaluasi Kualitas Informasi Situs Web Pemerintah Kota Bitung. In Seminar Nasional Teknologi Komputer \& Sains (SAINTEKS) (Vol. 1, No. 1, pp. 7-12).

Noviana, R., Sulandari, S., \& Lituhayu, D. (2015). Manajemen e-Government Berbasis Web Model Government-to-Citizen (G2C) Pada Dinas Kebudayaan dan Pariwisata Provinsi Jawa Tengah 
(Doctoral dissertation, Diponegoro University).

Riadi, M. E-Government (Pengertian, Tujuan, Jenis dan Strategi Pengembangan) - KajianPustaka.com Https://www.kajianpustaka.com/, Jan. 2020. https://www.kajianpustaka.com/2020/01/egovernment-pengertian-tujuan-jenis-dan-strategipengembangan.html (accessed Oct. 12, 2020).

S. Angreni and R. T. Sari, "Ketersediaan Dan Pemanfaatan Media Komponen Instrumen Terpadu (Kit) Ipa Di Sd Negeri Kecamatan Nanggalo Kota Padang," J. Pendidik. Nusant., vol. 2, no. 2, pp. 234-242, 2017.

Sitokdana, M. N. (2015). Evaluasi Implementasi eGovernment Pada Situs Web Pemerintah Kota Surabaya, Medan, Banjarmasin, Makassar dan
Jayapura.J. Buana Inform., vol. 6, no. 4, pp. 289-300, 2015, doi: 10.24002/jbi.v6i4.461.

Somantri, O., \& Hasta, I. D. (2017). Implementasi eGovernment Pada Kelurahan Pesurungan Lor Kota Tegal Berbasis Service Oriented Architecture (SOA). Jurnal Informatika: Jurnal Pengembangan IT, 2(1), 23-29.

Tonggiroh, M. (2017, November). Digital Government Services in Papua. In 2017 Second International Conference on Informatics and Computing (ICIC) (pp. 1-6). IEEE.

Tunggal, A. C. (2015). Studi Deskriptif Rekrutmen dan Seleksi pada PT. Multi Artistikacithra. Agora, 3(1), 647-650. 